\title{
Zirconium Recycle Test Equipment for Hot Cell Operations
}

\section{Fuel Cycle Research \& Development}

\author{
Prepared for \\ U.S. Department of Energy \\ Fuel Cycle Research and Development \\ E. D. Collins, G. D. DelCul, B. B. Spencer, \\ R. R. Brunson, E. C. Bradley \\ Oak Ridge National Laboratory \\ 30-January-2015 \\ FCRD-MRWFD-2015-000407 \\ ORNL/LTR-2015/29
}




\section{DISCLAIMER}

This information was prepared as an account of work sponsored by an agency of the U.S. Government. Neither the U.S. Government nor any agency thereof, nor any of their employees, makes any warranty, expressed or implied, or assumes any legal liability or responsibility for the accuracy, completeness, or usefulness, of any information, apparatus, product, or process disclosed, or represents that its use would not infringe privately owned rights. References herein to any specific commercial product, process, or service by trade name, trade mark, manufacturer, or otherwise, does not necessarily constitute or imply its endorsement, recommendation, or favoring by the U.S. Government or any agency thereof. The views and opinions of authors expressed herein do not necessarily state or reflect those of the U.S. Government or any agency thereof. 


\section{CONTENTS}

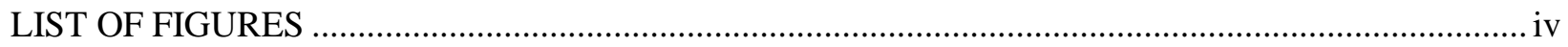

STATUS REPORT—EXPERIMENTAL EQUIPMENT PREPARATION FOR HOT CELL TESTING 


\section{LIST OF FIGURES}

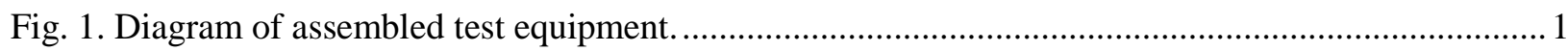

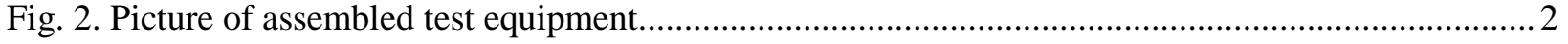




\section{Zirconium Recycle Test Equipment for Hot Cell Operations}

\section{STATUS REPORT-EXPERIMENTAL EQUIPMENT PREPARATION FOR HOT CELL TESTING}

The equipment components and assembly support work were modified for optimized, remote hot cell operations as illustrated in Figures 1 and 2 to complete this milestone. The modifications include installation of a charging door, Swagelok connector for the off-gas line between the reactor and condenser, and slide valve installation to permit attachment/replacement of the product salt collector bottle.

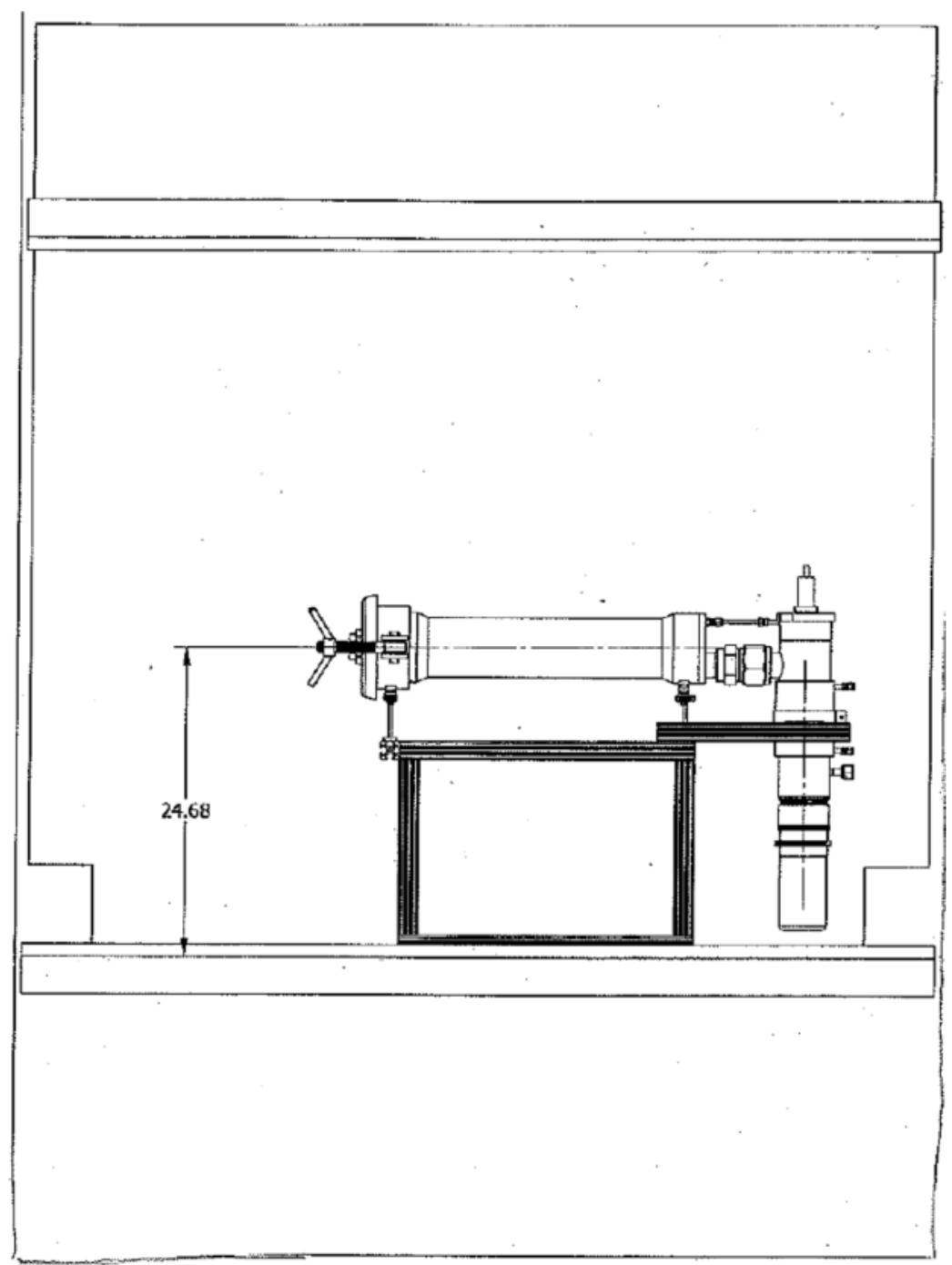

Fig. 1. Diagram of assembled test equipment. 


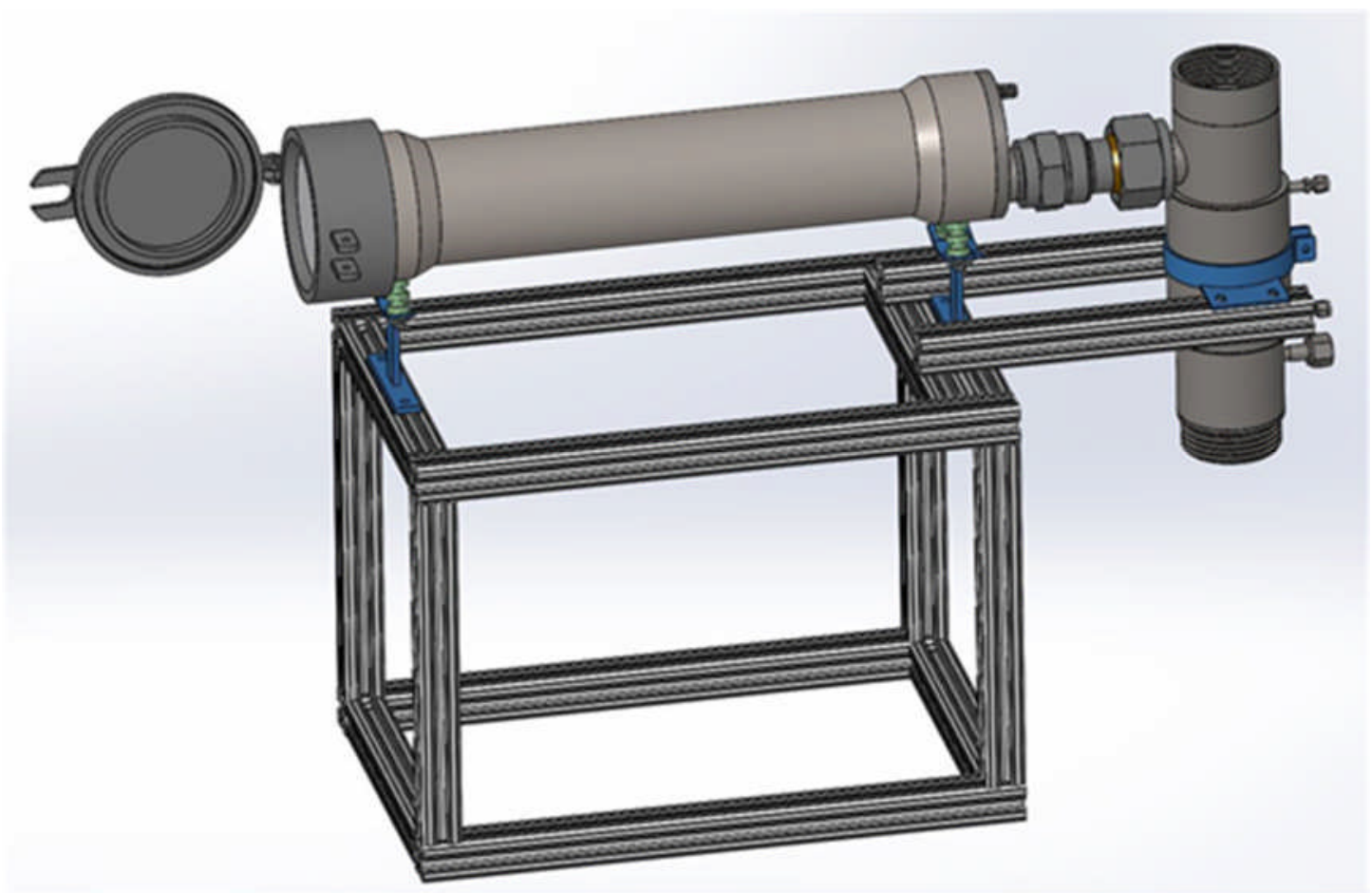

Fig. 2. Picture of assembled test equipment.

The latter will enable collection of product fractions during each test operation for subsequent mass balance weighing and sampling. The reactor currently contains a removable tray for containment of the cladding tubes and residual ash for mass balance weighing/sampling capabilities.

The assembled equipment will be moved to the laboratory containment box for non-rad testing and determination of any further modifications that may be required. Various methods of heating/cooling will be tested to select the optimum method for use in hot cell operations. 